\title{
BioLink
}

Jurnal Biologi Lingkungan, Industri, Kesehatan

Available online http://ojs.uma.ac.id/index.php/biolink

\section{EFFECTIVENESS TEST OF BLACK CUMIN SEEDS (NIGELLA SATIVA) EXTRACT ON THE GROWTH OF KLEBSIELLA PNEUMONIAE AND PSEUDOMONAS AERUGINOSA BACTERIA}

\section{Nadya Nazimuddin Putri *, Linda Chiuman, Chrismis Novalinda Ginting, \& Ermi Girsang}

Biomedical Science Masters Study Program, Faculty of Medicine, Universitas Prima Indonesia, Indonesia

Submited : 24-04-2020; Reviewed :06-10-2020; Accepted : 18-12-2020

*Corresponding author: E-mail : nadyanp.dr@gmail.com

\begin{abstract}
Black cumin seeds are known to have beneficial contents as antibacterial. This study aimed to determine the effectiveness of black cumin seed extract (Nigella sativa) on the growth of Klebsiella pneumoniae and Pseudomonas aeruginosa. The method used was the disc diffusion method. The ethanol extract of black cumin seeds gain by maceration method and was made into various concentration $(5,7.5,10,12.5$, and 15)\%. For positive control, ciprofloxacin disc were used and negative control used distilled water. The research model used was in vitro experimental research. The results showed that ethanol extract of black cumin seeds have antibacterial activity against Klebsiella pneumoniae with inhibition zone diameters (4.5, $6.7,10.1,11,12.8) \mathrm{mm}$, Pseudomonas aeruginosa with inhibition zone diameters $(7.5,12,12.6,13.4,15.6)$ $\mathrm{mm}$, positive controls respectively (24.3 and 20.7) $\mathrm{mm}$ and negative controls (0). It can be concluded that black cumin seed extract has an inhibiting effect on the growth of Klebsiella pneumoniae and Pseudomonas aeruginosa.
\end{abstract}

Keywords: Black Cumin Seed; Disc Diffusion; Ethanol Extract; Klebsiella pneumoniae; Pseudomonas aeruginosa

How to Cite: Putri, N.N., Chiuman, L., Ginting, C.N., \& Girsang, E. (2021). Effectiveness Test Of Black Cumin Seeds (Nigella sativa) Extract On The Growth Of Klebsiella pneumoniae and Pseudomonas aeruginosa Bacteria, BioLink: Jurnal Biologi Lingkungan, Industri dan Kesehatan, Vol.7 (2): Hal. 130- 138 
Putri, N.N., Chiuman, L., Ginting, C.N., \& Girsang, E. Effectiveness Test Of Black Cumin Seeds (Nigella sativa) Extract On The Growth Of Klebsiella pneumoniae and Pseudomonas aeruginosa Bacteria

\section{INTRODUCTION}

Hospital-acquired pneumonia (HAP) or respiratory infection that occurs in health facilities is a health problem that we often encounter in the scope of work of medical personnel in the world. Most cases of nosocomial infections in hospitals are caused due to the use of medical devices such as ventilators, catheters, use of intravenous lines, or postoperative infections. HAP cases are most often caused by gram-negative bacilli such as Pseudomonas aeruginosa, Eschericia coli, Klebsiella pneumoniae, and Acinetobacter sp. Patients who are hospitalized in the hospital usually have weak immunity so that are getting infection easily (Bennett, 2018).

\section{Klebsiella pneumoniae and} Pseudomonas aeruginosa are pathogenic bacteria that often attack patients with weak immunity. These two bacteria often cause the high morbidity and mortality in HAP due to antibiotic resistance (Craven et al., 2010).

The high incidence of resistance has made a lot of research on plants to be used as antibacterial agents, one of them is black cumin seeds (Nigella sativa). According to Al-Jassir (2008), black cumin seeds have the ability to be anti-histamine, antidiabetes, anti-hypertensive, antiinflammatory, anti-bacterial, anti-fungal, anti-cancer, and enhancing immunity (Forouzanfar et al., 2014). The antibacterial effect of black cumin seeds is caused by the content of thymohydroquinone, dithymoquinone, alkaloids, triterpene, saponins, thymol, and others which denature proteins in the bacterial cell wall and damage the bacterial cell cytoplasm (Sultana et al., 2015; Silvani NS., 2018; Tacakkoli et al., 2017).

The type of black cumin seeds itself can affect the antibacterial activity produced, such as a study (Bakathir et al., 2011) where the researchers compared the antibacterial activity between types of black cumin seeds obtained in Ethiopia and Hadramout against Staphylococcus aureus. The results showed that the black cumin seeds obtained from Hadramout were stronger than those obtained in Ethiopia. This could be due to geography and the season when the cumin seeds were harvested.

Black cumin seeds have antibacterial benefits which have been proven by (Foroughi et al., 2016) that black cumin seeds inhibit the growth of Eschericia coli, Staphylococcus aureus, and Bacillus subtilis by the disc and well diffusion method at concentrations of $0.3 \%, 0.7 \%, 1.5 \%, 3 \%$, $6 \%$, and $12.5 \%$ and the minimum inhibitory levels were obtained at a concentration of $3 \%$ against the growth of 
Escherichia coli and Staphylococcus aureus

while the minimum inhibitory levels on the growth of Bacillus subtilis occurred at a concentration of $1.5 \%$. Other studies have also shown that black cumin had strong bacterial inhibition against gram-positive bacteria but weak against gram-negative bacteria (Bakathir et al., 2011; Butar-Butar, 2018; Hannan et al., 2008).

Based on the description above, it is necessary to conduct a research to determine the effectiveness of black cumin seed extract (Nigella sativa) on the growth of the bacteria Klebsiella pneumoniae and Pseudomonas aeruginosa.

\section{MATERIALS AND METHODS}

This research was conducted at the Laboratory of Microbiology, Faculty of Medicine, Prima Indonesia University, Medan and the process of extracting black cumin seeds was carried out at the USU Mathematics and Natural Sciences Laboratory. This research was conducted from May to June 2019. This type of research used a pure laboratory experimental method with a post-test only group design approach. 1000gr of black cumin obtained from the Indian market, Medan was used as the research sample. Klebsiella pneumoniae and Pseudomonas aeruginosa bacteria were isolated and incubated in NA medium at $37^{\circ} \mathrm{C}$ for 24 hours.
The tools in this study were petri dishes, autoclave, aluminum foil, measuring cup, erlenmeyer, filter funnel, filter paper, disc paper, analytical balance, ose needle, test tube, tweezers, object glass, dropper pipette, camera, cotton pad, caliper. , and stationery.

The materials used were black cumin, distilled water, Nutrient Agar, Mc Farland solution, sterile $\mathrm{NaCl}, \quad$ Klebsiella pneumoniae culture, Pseudomonas aeruginosa culture, ciprofloxacin antibiotic $\operatorname{disc} 5 \mu / \mathrm{L}$, and $96 \%$ ethanol.

Making Black Cumin Seed Extract. $1000 \mathrm{gr}$ of black cumin, mashed and soaked in $5000 \mathrm{ml}$ of $96 \%$ ethanol. Macerated for one week at room temperature. The filtrate results were then in a rotary evaporator.

Concentration Making. The concentrations used were $5 \%, 7.5 \%, 10 \%$, $12.5 \%$, and $15 \%$. Aquadest as a negative control and ciprofloxacin as a positive control. The calculation for the concentration of black cumin seed extract used the following dilution formula:

$$
\mathrm{V} 1 \times \mathrm{M} 1=\mathrm{V} 2 \times \mathrm{M} 2
$$

Making NA Media and Bacterial Culture. NA powder was weighed as much as $20 \mathrm{gr}$ in 1 liter of distilled water and stirred until homogeneous and autoclaved. NA was poured into a petri dish and stored in the refrigerator until hardened. NA medium was then given a pure culture smear of Klebsiella pneumoniae. The same 
Putri, N.N., Chiuman, L., Ginting, C.N., \& Girsang, E. Effectiveness Test Of Black Cumin Seeds (Nigella sativa) Extract On The Growth Of Klebsiella pneumoniae and Pseudomonas aeruginosa Bacteria

thing was done for pure cultures of 2018 for Windows program which started Pseudomonas aeruginosa (Wadud, 2014). with the normality test and homogeneity

Testing stage. Empty test discs soaked in black cumin seed extract of various test to find out which test to use and continues with post hoc analysis. concentrations were placed on the agar surface with the Klebsiella pneumoniae bacteria culture. The media was then incubated at $37^{\circ} \mathrm{C}$ for 24 hours and then the diameter of the clear area was measured using a caliper. The same thing was done with the Pseudomonas aeruginosa bacteria.

Data processing. Data processing which includes editing, tabulation and grouping was done manually using

RESULTS AND DISCUSSION

\section{Antibacterial Test of Black Cummin} Seed Ethanol Extract

This study used the disc diffusion method test with three repetitions with extract concentrations of $5 \%, 7.5 \%, 10 \%$, $12.5 \%$, and $15 \%$. Below is a picture of the antibacterial test of ethanol extract of black cumin seeds against Klebsiella pneumoniae and Pseudomonas aeruginosa on agar media as follows:

Microsoft Office Word 2019 and the SPSS

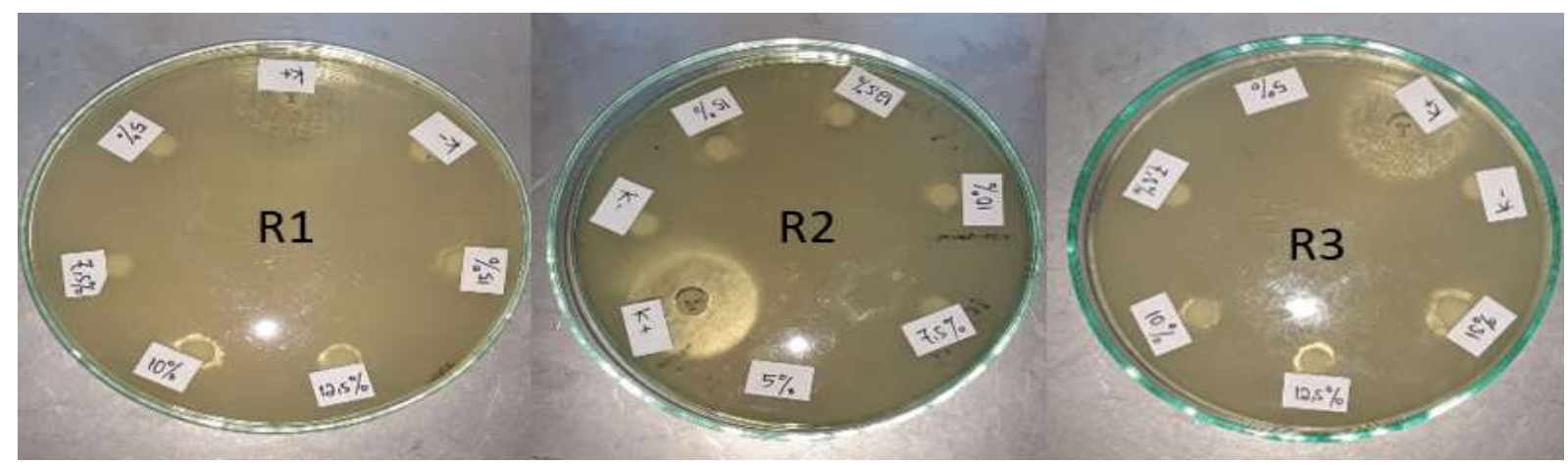

Figure 1. Ethanol Extract of Black Cumin Seed Against Klebsiella pneumoniae Bacteria

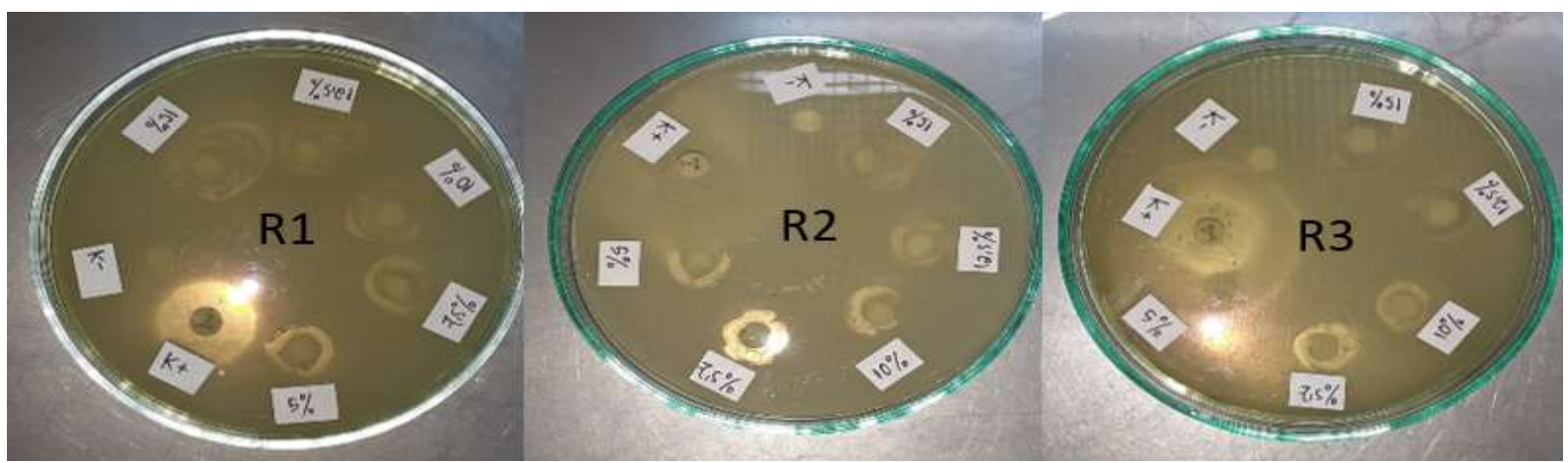

Figure 2. Ethanol Extract of Black Cumin Seed Against Pseudomonas aeruginosa Bacteria 
From Figure 1 and 2, the broadest compared to black cumin seed extract. The inhibition zone was produced by positive results of the inhibition zone measurement control for both types of bacteria are presented in the following table:

Table 1. Results of Inhibition Zone Diameter Measurement

\begin{tabular}{cccccc}
\hline \multirow{2}{*}{ Test Bacteria } & Treatment & \multicolumn{4}{c}{ Zone of resistance (mm) } \\
\cline { 2 - 5 } & & $\mathbf{R 1}$ & $\mathbf{R 2}$ & $\mathbf{R 3}$ & Average \\
\hline \multirow{2}{*}{ Control +} & 22.1 & 25.2 & 25.5 & 24.3 \\
& Control - & 0 & 0 & 0 & 0 \\
& $5 \%$ & 6.7 & 6.7 & 0 & 4.5 \\
& $7.5 \%$ & 6.8 & 6.7 & 6.7 & 6.7 \\
& $10 \%$ & 10.8 & 9.6 & 9.8 & 10.1 \\
& $12.5 \%$ & 11.6 & 10.9 & 10.5 & 11 \\
& $15 \%$ & 12.8 & 12.9 & 12.8 & 12.8 \\
\hline \multirow{2}{*}{ Pseudomonas aeruginosa } & Control + & 20.6 & 20.7 & 20.8 & 20.7 \\
& Control - & 0 & 0 & 0 & 0 \\
& $5 \%$ & 12.1 & 10.3 & 0 & 7.5 \\
& $7.5 \%$ & 12.5 & 10.7 & 12.9 & 12 \\
& $10 \%$ & 13.4 & 11.1 & 13.3 & 12.6 \\
& $12.5 \%$ & 14.0 & 12.1 & 14.2 & 13.4 \\
& $15 \%$ & 16.1 & 14.6 & 16.1 & 15.6 \\
\hline
\end{tabular}

From table 1 above, the results showed that the highest inhibition zone in black cumin seed extract against Klebsiella pneumoniae was found at a concentration of $15 \%$ with an average inhibition zone of

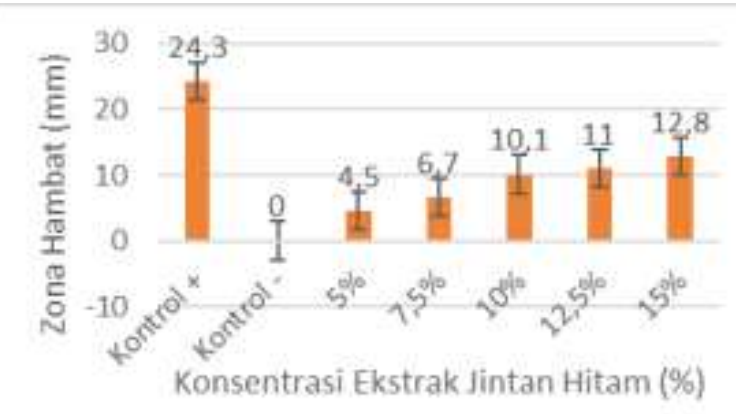

Figure 3. The Average Diameter of the Inhibition Zone of Black Cumin Extract against Klebsiella pneumoniae
$12.8 \mathrm{~mm}$ and in Pseudomonas aeruginosa the highest inhibition zone was also found at a concentration of $15 \%$ with an average inhibition zone diameter $15.6 \mathrm{~mm}$.

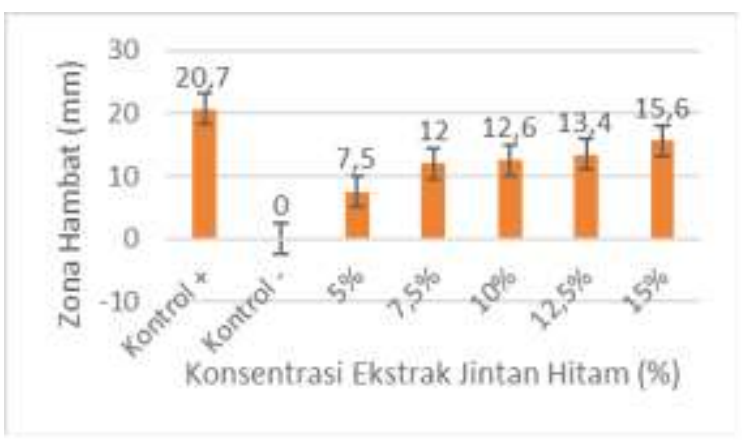

Figure 4. Average Diameter of the Inhibition Zone of Black Cumin Extract against Pseudomonas aeruginosa 
Putri, N.N., Chiuman, L., Ginting, C.N., \& Girsang, E. Effectiveness Test Of Black Cumin Seeds (Nigella sativa) Extract On The Growth Of Klebsiella pneumoniae and Pseudomonas aeruginosa Bacteria

Figures 3 and 4 above show the inhibition, 10-20 $\mathrm{mm}$ had strong inhibition, results of the calculation of the average and $\geq 20 \mathrm{~mm}$ have very strong inhibition. inhibition zone in the form of a graph From the criteria for the inhibition of black that indicate the largest extract cumin seed extract against Klebsiella inhibition zone diameter produced by a pneumoniae and Pseudomonas aeruginosa concentration of $15 \%$ with a value of varied between weak and strong depending $12.8 \mathrm{~mm}$ for Klebsiella pneumoniae and on the concentration of the extract.

15.6mm for Pseudomonas aeruginosa.

Based on the bacterial inhibition criteria according to David and Stout in Rita (2010), it was found that if the diameter of the inhibition zone formed was $\leq 5 \mathrm{~mm}$, the extract had weak Statistical Test of Antibacterial Significance of Black Cumin Seed Extract

The results of the post hoc test analysis used the Mann-Whitney test with the following results:

inhibition, 5-10 $\mathrm{mm}$ had moderate

Table 2. Results of Post Hoc Analysis of Black Cumin Seed Extract on the Growth of Klebsiella pneumoniae Bacteria

\begin{tabular}{|c|c|c|c|c|c|c|c|}
\hline Treatment & $5 \%$ & $7.5 \%$ & $10 \%$ & $12.5 \%$ & $15 \%$ & Control + & Control - \\
\hline $5 \%$ & & 0.197 & 0.046 & 0.046 & 0.043 & 0.046 & 0.114 \\
\hline $7.5 \%$ & & & 0.046 & 0.046 & 0.043 & 0.046 & 0.034 \\
\hline $10 \%$ & & & & 0.127 & 0.046 & 0.050 & 0.037 \\
\hline $12.5 \%$ & & & & & 0.046 & 0.050 & 0.037 \\
\hline $15 \%$ & & & & & & 0.046 & 0.034 \\
\hline Control + & & & & & & & 0.037 \\
\hline Control - & & & & & & & \\
\hline
\end{tabular}

From table 2 above, there were significant differences $(p<0.05)$ in all concentrations against negative controls except at 5\% concentration. This indicates that the black cumin seed extract inhibits the growth of the Klebsiella pneumoniae bacteria. 
Table 3. Results of Post Hoc Analysis of Black Cumin Seed Extract on the Growth of Pseudomonas aeruginosa Bacteria

\begin{tabular}{cccccccc}
\hline Treatment & $\mathbf{5 \%}$ & $\mathbf{7 . 5 \%}$ & $\mathbf{1 0 \%}$ & $\mathbf{1 2 . 5 \%}$ & $\mathbf{1 5 \%}$ & Control + & Control - \\
\hline $5 \%$ & & & & & & & \\
\hline $7.5 \%$ & 0.127 & 0.127 & 0.077 & 0.046 & 0.050 & 0.121 \\
$10 \%$ & & 0.275 & 0.275 & 0.046 & 0.050 & 0.034 \\
$12.5 \%$ & & & 0.275 & 0.046 & 0.050 & 0.037 \\
$15 \%$ & & & & 0.046 & 0.050 & 0.037 \\
Control + & & & & & 0.046 & 0.034 \\
Control - & & & & & & 0.037 \\
\hline
\end{tabular}

From table 3 above, there was a significant difference $(\mathrm{p}<0.05)$ at a concentration of $15 \%$ against negative controls. It showed that there was an inhibitory power at a concentration of $15 \%$ black cumin seed extract against the growth of the bacteria Pseudomonas aeruginosa.

In this study, the sample was generated by the ethanol $96 \%$ maceration method so that there were less active compounds in the extract of this study. The inhibition of growth of the bacteria Klebsiella pneumoniae and Pseudomonas aeruginosa was greater in line with the high concentration of black cumin seed extract used.

The results showed that the black cumin seed extract had an effect in inhibiting the growth of Klebsiella pneumoniae and Pseudomonas aeruginosa at concentrations of $5 \%, 7.5 \%, 10 \%, 12.5 \%$, and $15 \%$.
Kruskal-Wallis nonparametric test with a result of $p<0.05$ which proved the effect of black cumin seed extract in inhibiting the growth of the bacteria Klebsiella pneumoniae and Pseudomonas aeruginosa. It is in accordance with the research by (Hassan et al., 2008) regarding the activity test of Nigella sativa as an antibacterial against the growth of Staphylococcus aureus, Pseudomonas aeruginosa, Klebsiella pneumoniae, Eschericia coli, and Bacillus cereus bacteria. In his research, the process of extracting black cumin seeds used methanol solvent and with concentrations of $25 \mathrm{mg} / 20 \mu \mathrm{L}, 50 \mathrm{mg} / 20 \mu \mathrm{L}$, and $100 \mathrm{mg} /$ $20 \mu \mathrm{L}$. The result of the inhibition of bacterial growth was weak.

Likewise, the results of other studies that tested the effects of black cumin seeds with the Soxhlet extraction method and methanol maceration against 21 Pseudomonas aeruginosa strains that were resistant to several types of antibiotics with

The data were analyzed using the the results of methanol extract had better 
Putri, N.N., Chiuman, L., Ginting, C.N., \& Girsang, E. Effectiveness Test Of Black Cumin Seeds (Nigella sativa) Extract On The Growth Of Klebsiella pneumoniae and Pseudomonas aeruginosa Bacteria

inhibition than the essential oil extract with inhibitory results against Pseudomonas aeruginosa. 12 and 11 strains were resistant to antibiotics, respectively (Salman et al., 2008).

The differences between this study and the two studies conducted were the type of black cumin seeds, the concentration used, and the type of solvent in extracting the black cumin seeds.

\section{CONCLUSION}

From the results of the study, it can be concluded that the ethanol extract of black cumin seeds using the disc diffusion method had been proved to have an effect in inhibiting bacterial growth by obtaining inhibition zone in Klebsiella pneumoniae with extract concentrations of 5\%, 7.5\%, $10 \%, 12.5 \%$, and $15 \%$, respectively. were $4.5,6.7,10.1,11$, and $12.8 \mathrm{~mm}$ and in Pseudomonas aeruginosa 7.5, 12, 12.6, 13.4, and $15.6 \mathrm{~mm}$. The higher the concentration of black cumin seed extract, the stronger the antibacterial effect against Klebsiella pneumoniae and Pseudomonas aeruginosa.

\section{REFERENCES}

Al-Jassir, MS. (2008). Chemical Composition and Microflora of Black Cumin (Nigella sativaL.) and Aleppo Pine (Pinus halpensis Mill.) Seed Oils. J Food Comp Anal. 21(2): 162-168

Bakathir, HA., \& Abbas NA. (2011). Detection of the Antibacterial Effect of Nigella sativa Ground
Seeds with Water. Afr J Tradit Complement Altern Med. 8(2): 159-164

Butar-Butar, RR. (2018). Uji Efektivitas Ekstrak Jintan Hitam Terhadap Pertumbuhan Staphilokokus aureus Isolat Pus Infeksi Odontgenik. Skripsi. Medan: Universitas Sumatera Utara.

Craven DE. \& Chroneou A. Nosocomial Pneumonia. dalam: Mandell G.L., Bennett J. E., dan Dolin R (Eds). (2010). Principles and Practice of Infectious Disease. 2(7): 3717-24. Philadelphia: Elsevier.

Bennett J. (2018). BMJ Best Practice: HospitalAcquired Pneumonia. Diunduh di https://bestpractice.bmj.com/topics/en$\mathrm{gb} / 720$ tanggal 1 Juni 2019.

Foroughi A., Pournaghi P., Tahvilian R., Zangeneh MM., Zangeneh A., \& Moradi R. (2016). Ethnomedicinal Plants: Study on the Chemical Composition and Antibacterial Activity of the Nigella sativa (Black Seed) Oil's. International Journal of Pharmaceutical and Clinical Research. 8(11): 1528-1532.

Forouzanfar F., Bazzaz B.S.F., \& Hosseinzadeh H. (2014). Black Cumin (Nigella sativa) and Its Constituent (Thymoquinone): A Review on Antimicrobial Effects. Iran J Basic Med Sci: 929-938

Hannan A., Saleem S., Chaudhary S., Barkaat M., \& Arshad MU. (2008). Antibacterial Activity of Nigella sativa Against Clinical Isolates of Methicillin Resistant Staphylococcus aureus. J Ayub Med Coll Abbottabad. 2o(3):72-74

Hassan Z., Fairuz A.R.M., Zakri A.H.Z., \& Rahim M.N.A. (2008). In vitro Antibacterial Activity of Nigella sativa Against Staphylococcus aureus, Pseudomonas aeruginosa, Klebsiella pneumoniae, Eschericia coli and Bacillus cereus. Asian Journal of Plant Sciences. 7(3):331-333

Rita, WS. (2010). Isolasi Identifikasi dan Uji Aktivitas Antibakteri Senyawa Golongan Triterpenoid pada Rimpang Temu Putih (Curcuma zedoaria (Berg) Roscoe). Jurnal Kimia. 4:20-26

Salman, MT., Khan RA., \& Shukla I. (2008). Antimicrobial activity of Nigella sativa Linn. 
Seed Oil Against Multi-Drug Resistant Bacteria From Clinical Isolates. Natural Product Radiance. 7(1): 10-14

Silvani, NS. (2018). Kajian Aktivitas Antimikroba

Ekstrak Jintan Putih (Cuminum cyminum) Terhadap Mikroba Patogen dan Perusak Pangan. Skripsi. Bogor: Institut Pertanian Bogor.

Sultana S., Muhammad H., Akhtar N., \& Iqbal A. (2015). Nigella sativa: Monograph. Journal of Pharmacognosy and Phytochemistry. 4(4): 103-106.
Tacakkoli A., \& Mahdian V. (2017). Review on Clinical Trials of Black Seed (Nigella sativa) and Its Active Constituent, Thymoquinone. Journal of Pharmacopuncture. 20(3): 179-193 Wadud, SA. (2014). Uji Efektivitas Ekstrak Biji Jintan Hitam (Nigella sativa) Terhadap Pertumbuhan Bakteri Shigella dysenteriae. Skripsi. Jakarta: UIN Syarif Hidayatullah Jakarta. 